\title{
INFLUENCE OF DISTRIBUTIVE JUSTICE ON JOB SATISFACTION: A FOCUS ON EMPLOYEES IN NIGERIA PORT AUTHORITY
}

\author{
Waribo, Young \\ Department of Business Management, Covenant University, Ota, Ogun State, Nigeria.
}

Akintayo, Dayo I

Osun State University, Nigeria

Osibanjo, Adewale Omotayo

Department of Business Management, Covenant University, Ota, Ogun State, Nigeria.

Fadeyi, Olatunji Idowu

Anchor University, Lagos, Nigeria

\begin{abstract}
Arising from the fact that it has become pertinent to establish a research agenda that can guide managerial efforts ethical conducts that will be perceived as workplace or organizational justice, especially with respect to distributive justice, hence, this research is focused on investigating the influence of distributive justice on employees' job satisfaction. The descriptive survey research design was used for this study. The sample size for this study included three hundred and twenty-five (325) staff of the Nigerian Ports Authority. Using the multiple regression analysis, the study revealed that that distributive justice has significant influence on employees' satisfaction. Consequently, the study suggested that deliberate effort should be made to install and run a system whereby distribution of outcomes, particularly financial rewards should be performance based and reviewed at regular intervals in light of prevailing socioeconomic circumstances.
\end{abstract}

Keywords: Organizational justice, Distributive justice, Employee satisfaction, Job satisfaction, Workplace justice.

Cite this Article : Waribo, Young, Akintayo, Dayo I, Osibanjo, Adewale Omotayo and Fadeyi, Olatunji Idowu, Influence of Distributive Justice on Job Satisfaction: A Focus on Employees in Nigeria Port Authority, International Journal of Management, 10(3),2019,pp.69-76,

http://iaeme.com/Home/issue/IJM?Volume=10\&Issue $=3$ 


\section{INTRODUCTION}

By distributive justice, reference is being made to the perceived fairness of the decisions and distribution of outcomes, precisely remuneration among two or more parties (Aggarwal-Gupta and Kumar, 2010), who monitor actual outcomes received with ideal or expected outcomes (Alder and Ambrose, 2005; Greenberg, 2006). Thus, employees look forward to receiving outcomes that are proportional to their contributions, which are defined by the principle of equity. It is a given that employees will regulate their contributions to match remuneration, which is backed up by equity theory and corroborated by empirical studies when injustice is perceived in the input/outcome ratio (Wang, et al., 2010). Evidently, employees do not just compare their input - outcome ratio, they also compare their earnings with that of their peers as highlighted by the Relative Deprivation theory (Aggarwal-Gupta and Kumar, 2010). Their observation of fairness influences their conflict management styles as they interact with other stakeholders (Geeta, Pooja and Renu, 2011; Rowland and Hall, 2012).

Furthermore, the desire to achieve and sustain equity and fairness is common to man everywhere. But sadly, it is observed that despite man's effort to seek, achieve and sustainably retain equity and fairness, partial success seems to have been recorded thus far (Galtung, 1995). This is a worrisome global problem that seems to defy absolute solution; especially as perceived injustice is a potential cause of dissatisfaction. Dissatisfaction could influence employees' behaviours leading to unacceptable and unrewarding work outcomes that can degenerate to full blown conflict situations (Akikibofori \& Akikibofori, 2014; Jones and George, 2003: Mazni \& Roziah, 2011). Therefore, it has become pertinent to establish a research agenda that can guide managerial efforts ethical conducts that will be perceived as workplace or organizational justice, especially with respect to distributive justice. Hence, this research is focused on investigating the influence of distributive justice on employees' job satisfaction.

\section{LITERATURE REVIEW}

\subsection{Distributive Justice}

Distributive justice is founded on some theories which include Social Exchange theory with two assumptions about human behaviour; these assumptions are existence of a social exchange process and individual evaluation of fairness. The social exchange theory posit that individuals expect certain outcomes in return for the contributions they make through an exchange process; while the individual evaluation of fairness assert that individuals assess fairness of exchange with the aid of information gained through the social interaction (Thurston and McNall, 2010). Social exchange relationship is also established with the organisation in addition to the economic exchange relationship (Wang et al., 2010). The Relative Deprivation theory is the second basis for distributive justice. This theory posits that employees, especially those in the lower cadre use upward comparison of outcomes received to ascertain fairness (AggarwalGupta and Kumar, 2010).

\subsection{Employees Satisfaction}

Employee satisfaction has been a subject of interest to researchers and has been defined from different perspectives especially as it is posited to be vital in achieving and maintaining a happy and productive workforce in an ever-competitive business environment (Benko and Weisberg, 2007; Becker, 2007). In fact, Saari and Judge (2004) contend that employee job satisfaction is the most focal employees' behaviour. This position is corroborated by Usmani and Jamal (2013) who assert that job satisfaction is closely tied to employees' workplace behaviors. It is further argued that employees' satisfaction contributes to their mental and physical wellbeing (Becker, 2007; Jehad, Farzana and Mohmad, 2011; Osibanjo, Igbinoba, Falola, Awe, 2018). 
Job satisfaction has been defined as employees' positive emotional state resulting from assessment of job and other job-related experience (Luthans, 2011) and as the affective reaction of employees based on perceived favourable outcome when desired outcome is compared with actual outcome (Egan, Yang and Bartlett, 2004). It is also seen as the reflection of the degree of alignment of employees' job expectation with the realities of their job (Lund, 2003; Falola, Salau, Olokundun, Oyafunke-Omoniyi, Ibidunni \& Oludayo, 2018). This shows that employees' satisfaction is premised on intrinsic job elements like perception of the purpose of work and extrinsic factors like compensation. Thus, a mix of both intrinsic and extrinsic factors is required to produce employees' satisfaction (Egan, Yang, and Bartlett, 2004). Job satisfaction, which has been posited as a multi-dimensional variable is further described as the extent to which employees' expectation are fulfilled when the reward system is assessed independent of others available in the market (Ademola, 2012) and as individual employees' state of mind that evokes wants (Koontz and Donnel, 2005).

From the foregone, irrespective of differences in the definitions of employees' satisfaction, some major components of employees' satisfaction are deductible. These are attitude towards work group, general work conditions and attitude towards economy as well as monetary benefits and attitude tied to supervision. Other components of employees' satisfaction are employees' personality and state of mind as well as demographic and socio-political factors such as age, gender, education and skill level as well as individual aspiration and social status (Koontz and Donnel, 2005). Other factors influencing (antecedents) employees' satisfaction are supportive management and service climate (Ibidunni, Olokundun, Kehinde, Falola, Borishade \& Olusanmi, 2018). Supportive management refers to the concern that management shows about employee welfare; while service climate speaks to employee perception of the work environment and how much employers value their services (Bulgarella, 2005; Osibanjo, Abiodun and Adeniji, 2014). As a matter of fact, supportive management and service climate should encompass job design, compensation, work conditions and social relationships as well as perceived long-time opportunities for growth (Aziri, 2011). Practical employee satisfaction strategy should focus on identifying the root cause of dissatisfaction, benchmarking for best practices, developing employee satisfaction template of international standard and monitoring of employee satisfaction levels. Also organisations should continually see employees as invaluable assets and source of competitive advantage and treat them as such by showing true concern for their wellbeing, especially as fringe benefit is considered to enhance employee satisfaction (Koontz and Daniel, 2005; Ibidunni, Olokundun, Motilewa, Atolagbe \& Osibanjo, 2018). Very importantly, effective communication system that enhances mutual accountability must be maintained (Bulgarella, 2005) with the consciousness that employee satisfaction influences performance, absenteeism and turnover intention (Luthans, 2011).

\subsection{Organisational Justice and Job Satisfaction}

Ajala (2017) carried out a relationship study between organisational justice and job satisfaction among industrial employees in Ogun State, Nigerian and found that a strong relationship exists between all dimensions of organisational justice and job satisfaction as shown via the following ratings: distributive justice $(\mathrm{r}=0.955)$; procedural justice $(\mathrm{r}=0.968)$ and interactional justice $(\mathrm{r}=0.966)$ implying that perception of organisational justice has a direct influence on job satisfaction. Parvin and Kabir (2011) investigated the impact of some extrinsic factors (pay, working conditions, job security, workplace relationships and fairness) on employees' job satisfaction and the effect of demographic factors (age, sex, work experience) on attitude towards job satisfaction. The researcher found out that salary, workplace relationships and supervision are critical factors that contribute to employees' job satisfaction. Distributive justice was posited to have a strong, significant and a positive effect on employees; satisfaction as revealed in a study conducted by Ghadeer, (2014). The study suggested strongly that 
employers should be sensitive in the way they distribute both financial and non-financial outcomes as it directly influences employees' satisfaction.

Workplace relationship was found to influence employees' satisfaction. This is corroborated in a study conducted by Parvin and Kabir (2011) in the Pharmaceutical sector in Bangladesh. The referenced study found out that relationship between colleagues influenced employee satisfaction by a mean percentage of $66 \%$; while relationship with supervisors influenced satisfaction by a mean percentage of $56.2 \%$. This shows that interactional justice, precisely, interpersonal is significant in employee satisfaction. From the foregone, organisations must be deliberate in regulating employees' behavioural outcomes in general and employees' satisfaction in particular, especially as it is posited to be the most focal employees' behaviour (Saari and Judge, 2004). This infers that organisations must deliberately build in fairness into their system and structure, if they will successfully regulate employees' behavioural outcomes for both organisational, employees and societal benefit. As a matter of fact, all dimensions of organisational justice are crucial in enhancing employees' satisfaction as contained in the studies above. Precisely, salaries correlate with distributional justice, workplace relationships go along with interactive justice and work experience has to do with procedural justice. Thus, it is safe to conclude that organisational justice is central to achieving and sustaining employees' satisfaction, which is an antecedent to the much-desired affective work outcomes such as commitment, involvement and high performance, which leads to organisational profitability and growth.

\section{METHODOLOGY}

The descriptive survey research design was used for this study because it facilitated collection of data without manipulating any variable of interest in the study. Besides, it provided the opportunity to discuss the relationship between and among the various variables of interest and guaranteed equal chance of participation in the study on the part of the respondents.

\subsection{Sampling}

The sample size for this study was three hundred and twenty-five (325) which was subsequently increased by $30 \%$ to 423 as suggested by Isreal (2013). The sample size of 423 was proportionately distributed among staff of the selected Ports in Nigeria.

\subsection{Measures}

Items on distributive justice was measured using Niehoff and Moorman (1993) while employees' job satisfaction was measured using Allen Meyer's job commitment 10-item scale, which was validated by Akintayo and Ayodele (2012).

\subsection{Reliability of Scale}

The reliability of the instrument was ensured using internal consistency. The distributive justice scale (DJS) produce $\alpha=0.78$, while job satisfaction scale was $\alpha=0.81$.

\subsection{Analysis}

The gender section of respondents' demographic information shows that two hundred and fortyfour (244) of the respondents representing $60 \%$ were male out of the four hundred and five (405) while the remaining one hundred and sixty-one (161) respondents representing $40 \%$ were female. The age distribution of respondents was also captured in Table 4.2. Results revealed that thirty-four (34) respondents representing $8 \%$ were between the ages of 18 - 30 years, one hundred and sixty-eight (168) of the respondents representing $42 \%$ were between 31 - 40 years, one hundred and seventy-four (174) respondents representing 43\% were between 41 - 50 years; 
while twenty-nine (29) respondents representing 7\% were 51 years and above. Indication from the finding showed that most of the respondents were between the ages of $31-50$ (342) which represented $84 \%$. Other age groups were also represented. Data on the highest educational qualification of respondents revealed that sixteen (16) respondents, which form four (4\%) were holders of ordinary level West African School Certificate (WASC). Fifty-one (51) of the respondents form thirteen (13\%) and had either National Diploma (ND) or National Certificate in Education (NCE); while two hundred and sixty-six (266) of the respondents, which form sixty six (66\%) were either Higher National Diploma (HND) or Bachelors Degree holders. The remaining seventy-two (72) respondents that form seventeen (17\%) had Masters Degree.

Table 1 Multiple Regression Analysis of the Combined Influence of Distributive Justice Components on Employees' Job Satisfaction

\begin{tabular}{|c|c|c|c|c|c|c|}
\hline \multicolumn{2}{|r|}{ Model } & \multicolumn{2}{|c|}{$\begin{array}{l}\text { Unstandardized } \\
\text { Coefficients }\end{array}$} & \multirow{3}{*}{$\begin{array}{c}\text { Standardised } \\
\text { Coefficients } \\
\text { Beta } \\
\end{array}$} & \multirow{3}{*}{$\begin{array}{c}\mathbf{T} \\
8.212 \\
\end{array}$} & \multirow{3}{*}{$\begin{array}{l}\text { Sig. } \\
.000 \\
\end{array}$} \\
\hline & & $\mathrm{B}$ & Std. Error & & & \\
\hline \multirow{6}{*}{ DJ } & (Constant) & 1.531 & .186 & & & \\
\hline & Fair Job Schedule & .037 & .044 & .043 & .843 & .400 \\
\hline & Fair Pay & .198 & .042 & .255 & 4.704 & .000 \\
\hline & Fair Workload & .147 & .045 & .180 & 3.263 & .001 \\
\hline & Fair Reward & .111 & .044 & .139 & 2.543 & .011 \\
\hline & Fair Job Responsibilities & .051 & .043 & .062 & 1.187 & .236 \\
\hline \multicolumn{3}{|c|}{$\mathbf{R}$} & \multicolumn{4}{|c|}{$\mathbf{0 . 5 0 7}$} \\
\hline \multicolumn{3}{|c|}{$\mathbf{R}^{2}$} & \multicolumn{4}{|c|}{0.257} \\
\hline \multicolumn{3}{|c|}{ Adj. $R^{2}$} & \multicolumn{4}{|c|}{0.248} \\
\hline \multicolumn{3}{|c|}{ F-value } & \multicolumn{4}{|c|}{$27.602($ Sig. $=0.000)$} \\
\hline
\end{tabular}

Source: Researcher's Field Survey Result (2018)

The statistical results in Table 1 shows how much of the variance of the dependent variable (employees' job satisfaction) is explained by the model. In this case the R square is .257 if expressed by a percentage will be $25.7 \%$. This implies that the model explains $25.7 \%$ of the variance in the levels of employees' satisfaction in the Nigerian Ports Authority. The ANOVA assessment of the statistical significance as 0.000 . The F-value for the model was obtained by dividing the regression mean square (16.938) by the residual mean square (.614). The F-value for the model is equal to 27.602. Table 4.4.3 describes the variables that are statistically significant and with exclusive contribution to the model obtainable under the sig column in the table. It reveals the strength of the contributions of the independent variable (distributive justice) to the dependent variable (employees' satisfaction). The table revealed that distributive justice (0.000) made significant contributions to the model except for DJ 1 and DJ5 that were insignificant. The result shows that for one unit increase in organisational justice dimensions, there is a corresponding increase in employees' job satisfaction in the Nigerian Ports Authority.

Decision: The null hypothesis $\left(\mathrm{H}_{0}\right)$ was rejected and the alternate hypothesis $\left(\mathrm{H}_{1}\right)$ accepted. This means that distributive justice has significant influence on employees' satisfaction in Nigerian Ports Authority. 


\section{DISCUSSION}

The findings from this study is that distributive justice has significant influence on employees' satisfaction, especially in the Nigerian Ports Authority. The outcome from this study corroborate the findings of Ajala (2017) who carried out a study on the relationship between organisational justice and employees' job satisfaction among industrial employees in Ogun State, Nigerian and found that a strong relationship exists between all dimensions of organisational justice, particularly distributive justice $(r=0.955)$ and employees' job satisfaction. Again, the findings of this study is in sync with a study conducted by Ghadeer, (2014) who asserted that distributive justice had a strong, significant and positive effect on employees' job satisfaction. The study suggested strongly that employers should be sensitive in the way they distribute both financial and non-financial outcomes as it directly influences employees' satisfaction. From the foregone, organisations must be deliberate in regulating employees' behavioural outcomes in general and employees' satisfaction in particular, especially as it is posited to be the most focal employees' behavioural outcome (Saari and Judge, 2004).

\subsection{Implications and Conclusion}

The implication of the findings from this study for organization is that deliberate effort should be made to install and run a system whereby distribution of outcomes, particularly financial rewards should be performance based and reviewed at regular intervals in light of prevailing socio-economic circumstances. This will have a two-pronged effect on employees. Precisely, employees will perceive transparency of the reward system (distributive justice) and work legitimately towards increased earning. Secondly, employees will also perceive that the organisation is mindful of their wellbeing. These perceptions of fairness in distribution of outcomes will give rise to and enhance affective and acceptable employees' behavioural outcomes, particularly employees' job satisfaction.

\section{ACKNOWLEDGEMENT}

Authors will like to appreciate Covenant University, Nigeria for funding the publication of the findings from this study in this journal.

\section{REFERENCES}

[1] Aggarwal-Gupta, M. and Kumar, R, Look who's talking! Impact of communication relationship satisfaction on justice perceptions. Vikalpa: The Journal for Decision Makers, 35(3), 2010, pp 55-65.

[2] Ajala, E.M, A relationship study between organisational justice and job satisfaction among industrial employees in Ogun State, Nigerian. African Journal for the Psychological Study of Social Issues, 20 (2), 2017, pp 26-42.

[3] Akikibofori, J. S. and Akikibofori, M, The causes and impact of deviant behaviour in the work place. American Journal of Social Sciences, Arts and Literature 1(2), 2014, pp 1-11.

[4] Akintayo, D. I. and Ayodele, O.A, Organisational justice and behaviour of human resource in industrial organisations in South-West, Nigerian. Global Advanced Research Journal of Management and Business Studies, 1(6), 2012, pp 201-209.

[5] Alder, G. S., and Ambrose, M. L, towards understanding fairness judgments associated with computer performance monitoring: An integration of the feedback, justice, and monitoring research. Human Resource Management Review, 15, 2005, pp 43-67

[6] Benko, C. and Weisberg, A., Mass career customization: Aligning the workplace with today's nontraditional workforce. Boston, MA: Harvard University Press. Google Scholar, 2007 
[7] Bulgarella, C, C, Employee satisfaction and customer satisfaction: Is there a relationship? GuideStar Research, 2005, pp 1-6.

[8] Egan, T. M., Yang, B., and Bartlett, K. R, kThe effects of organisational learning culture and job satisfaction on motivation to transfer learning and turnover intention. Human Resource Development Quarterly, 15(3), 2004, pp 279-301. doi:10.1002/hrdq.1104.

[9] Falola, H. O., Salau, O. P., Olokundun, M. A., Oyafunke-Omoniyi, C. O., Ibidunni, A. S. \& Oludayo, O. A, Employees' intrapreneurial engagement initiatives and its influence on organisational survival. Business: Theory and Practice, 19, 2018, pp 9-16.

[10] Galtung, J, "Conflict resolution as conflict transformation: The first law of thermodynamics revisited", in K. Rupesinghe, ed., Conflict transformation. London: Macmillan, 1995

[11] Geeta, R., Pooja, G. and Renu, R, Effect of justice perception on managerial effectiveness. IUP Journal of Organizational Behavior, 10(2):2011, pp 7-20.

[12] Ghadeer, M. B. E A, Analyzing the relationships between organization justice dimensions and selected organizational outcomes - empirical research study. The Business and Management Review, 5 (5), 2014

[13] Ghadeer, M. B. E A, Analyzing the relationships between organization justice dimensions and selected organisational outcomes - empirical research study. The Business and Management Review, 5 (5), 2014

[14] Ibidunni, A. S., Olokundun, M. A., Motilewa, D. B., Atolagbe, T. M. and Osibanjo, O. A. (2018). Group-Tacit Knowledge and Organizational Effectiveness: Analysis of Effects Using a Mixed Method Approach. Business: Theory and Practice, 19, 2018, pp 135-145.

[15] Ibidunni, S. A., Olokundun, A. M., Kehinde, J. O., Falola, O. H., Borishade, T. T. and Olusanmi, O, Moderating Effect of Organizational Climate on a Task-Trait Leadership Orientation and Employee Commitment: The Nigerian Banking Experience. Academy of Strategic Management Journal, 17(2), 1-6, 1939-6104-17-2-183.

[16] Jehad, M., Farzana, Q. H. and Mohmad, A. A, Job satisfaction and organizational citizenship behaviour: An empirical study at higher learning institutions. Asian Academy of Management Journal, 16(2), 2011, pp 149-165.

[17] Jones and George, Organizational Conflict, Negotiation, Politics, and Change, contemporary management 3rd edition; PowerPoint Presentation by Charlie Cook. The McGraw-Hill Companies, Inc, 2003

[18] Mazni, A. and Roziah, M.R, towards developing a theoretical model on the determinants of workplace deviance among support personnel in the Malaysian Public Service Organisations. http://www.google.co.zhlenfsc1ient"psy-abl, 2011

[19] Niehoff, B.P. and Moorman, R.H, Justice as a mediator of the relationship between methods of monitoring and organisationalcitizenship behavior. Academy of Management Journal, 36, 1993, pp 527-556.

[20] Osibanjo, A. O., Abiodun, A. J., and Adeniji, A. A, Impact of job environment in job satisfaction and performance among Nigerian nurses. Journal of South African Research in Business and Technology. 11(5), 2014

[21] Osibanjo, A.O., Igbinoba, E.E., Falola, H.O., Awe, K.O., Dataset on social demographic and employee job satisfaction in the Nigerian manufacturing company. Data in Brief, 19, 2018, pp 13-15.

[22] Gaurav Gupta and Urvashi Singh, a Study of Erp System for Employee Satisfaction in an It Organization, International Journal of Management (IJM), Volume 5, Issue 10, October (2014), pp. 25-32

[23] Parvin, M. M. \& Kabir, M. M. N, Factors affecting employee job satisfaction of pharmaceutical sector. Australian Journal of Business and Management Research 1(9), 2011, pp 113-123

[24] Rowland, C.A. and Hall, R.D, Organisational justice and performance: Is appraisal fair? EuroMed Journal of Business, 7(3), 2012, pp 280-293. 
[25] Saari, L. M., and Judge, T. A, Employee attitudes and job satisfaction. Human Resource Management, 43(4), 2004, pp 295-407.

[26] Saari, L. M., and Judge, T. A, Employee attitudes and job satisfaction. Human Resource Management, 43(4), 2004, pp 295-407.

[27] Thurston, J.R, P.W. and Mcnail, L, Justice Perceptions of performance appraisal practices. Journal of Management Psychology, 25(3), 2010, pp 201-228.

[28] Usmani, S. and Jamal, S, Impact of distributive justice, procedural justice, interactional justice, temporal justice, spatial justice on job satisfaction of banking employees. Review of Integrative Business and Economics Research, 2(1), 2013

[29] Souad Douli, Ilyes Slimani, Kamel Berbaoui, The Impact of Organizational Justice On Organizational Citizenship Behavior In Naftal (GPL) Bechar Algeria. International Journal of Management, 8(3), 2017, pp. 169-179.

[30] Wang, X., Liao, J., Xia, D., and T. Chang, The impact of organizational justice on work performance mediating effects of organizational commitment and leader-member exchange. International Journal of Manpower, 31(6), 2010, pp 660-677. 